\title{
Research on the Present Situation, Problems and Countermeasures of Precision Poverty Alleviation in Badong County
}

\author{
Yahong Gong ${ }^{1}$ Weiliang $\mathrm{Tu}^{2, *}$ \\ ${ }^{1}$ Economics and Management of Yangtze University School, Jingzhou, 434023, Hubei \\ Email:1349317682@qq.com \\ ${ }^{2}$ Economics and Management of Yangtze University School, Jingzhou, 434023, Hubei \\ * Corresponding author: Weiliang Tu
}

\begin{abstract}
Targeted poverty alleviation means accurate identification, assistance and management of the poor. Through the analysis of the current situation of poverty and precision poverty alleviation practice in the rural areas of Badong county, we can find out the difficult problems in the precise poverty alleviation work and overcome the problem of poverty alleviation in the deep poverty-stricken areas. We should improve the strategy of targeted poverty alleviation through multiple channels, establish a long-term mechanism of poverty alleviation through industry, education, entrepreneurship, and improve the skills of poverty alleviation teams, in an effort to reduce the poor population in Badong county.
\end{abstract}

Keywords: targeted poverty alleviation, problem, long-term mechanism

\section{INTRODUCTION}

In the past, China mainly focused on the extensive poverty alleviation model. Later, the targeted poverty alleviation model was put forward in light of the extensive poverty alleviation model. The targeted poverty alleviation model was a scientific and effective program that accurately identified, assisted and managed the targets of poverty alleviation $^{[4]}$. Although China has made remarkable achievements in the fight against poverty, the number of poor people in rural areas is still very large. Major problems in poverty alleviation and development work are still facing and it is difficult to get rid of poverty. Therefore, we need to conduct in-depth research and actively devote ourselves to the fight against poverty.

\section{Basic Profile and Poverty Analysis in Badong County}

\subsection{General situation of Badong.}

Badong county is located in the southwest of Hubei province, Enshi tujia and miao autonomous region in the northeast, narrow terrain ups and downs, west and low in Wuling mountains, Wushan mountains, drooling XianJing bus mountains flows ${ }^{[1]}$. The total land area of 3354 square kilometers and an average slope of 28.6 degrees, it is a typical karst landform and a large county in mountainous areas. Badong county has jurisdiction over a development zone, 12 townships and 491 villages (neighborhood committees). In 2016, the resident population of Badong county was 570,000, among which more than 520,000 were rural residents, accounting for $91.23 \%$ of the total population of the county.

\subsection{Poverty situation.}

Badong county is one of the poorest counties and cities in Enshi autonomous prefecture. It is also one of the state-level poverty-stricken counties. There are 118 poverty-stricken villages in the county, with a total of 53,982 households and 172,539 people. Among them, 34,526 were poor households, accounting for $63.96 \%$ of the total. The number of poor households is 112,435 , accounting for $65.16 \%$ of the total population. 14,610 people, or $27.06 \%$ of the total households, were living in poverty; The number of low-income households was 49,114 , accounting for $28.47 \%$ of the total population. Take erxiangwan village as an example, the total area of the village is 20.2 square kilometers, and the mountain area is $17346 \mathrm{mu}$. Cultivated land area: $2656 \mathrm{mu}$; There are 22 groups of villagers under the jurisdiction of the whole village, and there are 2323 people in 674 households. There are 1600 poor families in 400 households, which are located in remote areas, surrounded by mountains, with inconvenient transportation and single industry. A single trip to the county takes nearly four hours, and the speed of getting information is very slow. Ear xiangwan village teem with corn, red potato, potato, rape and other cash crops, the village mainly to plant cash crops and go out to work to obtain income. 
the people ", problem solving, match strong selection in Badong county, a village "dagger squad", set up 322, 2376 party members and cadres to residency support, will in order to achieve the orderly work of poverty alleviation.

(1) Effects of topographic conditions. Badong county is a large mountainous county, surrounded by mountains, is located in the remote, transportation, information access is not convenient, the county's arable land area is small, rural population, per capita arable land area is less than $1 \mathrm{mu}$. Due to the fragmentation of arable land, it is difficult to use modern mechanical farming technology, agricultural products can not be commercialized, large-scale, professional production. (2) Farmer's family income is not stable, the source is more dispersive. Farmers with a higher level of education will choose to go out and do manual labor to support the elderly and children left behind at home. Others will grow crops at home, raise crops and do small jobs for others to earn income. Government subsidies are also part of farmers' income. (3) Industrial development is slow. Due to the "scale disadvantage" of the operation of industrial poverty alleviation projects, industrial poverty alleviation seldom supports a single poor household, rarely provides the possibility of different industrial development according to the needs of different poor households, and tends to concentrate funds to build a unified and large-scale operation mode ${ }^{[3]}$. The speed of industrial development is extremely slow, and industries with characteristics cannot give play to their own advantages, and it is difficult to form brands. (4) Poor villagers have little incentive to lift themselves out of poverty. First, the villagers of the understanding of poverty alleviation is not enough, that poverty alleviation is a perfunctory; Second, the villagers "wait, rely on, want" thought seriously. (5) The phenomenon of poor people returning to poverty is more prominent. Once many rural poor population do not have policy support, due to illness, school, disability, disaster, lack of capital, lack of labor force, lack of technology and other reasons, the phenomenon of poverty is very serious.

\section{CURRENT SITUATION OF PRECISION POVERTY ALLEVIATION PRACTICE IN BADONG COUNTRY}

Since a crucial battle poverty, badong county has achieved 58 funding a dequeue, $29479 / 97924$ poor households out of poverty Feng, the results obtained in the poverty alleviation work basically has the following several aspects:

\subsection{Cadres in the village are stable and well organized.}

Mastering stationed in rural areas, in-depth understanding of Badong county villages poverty, village, mood to understand public opinion, is not only the supervisor, and guides, to assist the village two committees organized group, promote the party's principles and policies, guide the village cadres effective poverty alleviation work, for

\subsection{The project has achieved initial results.}

The county's 121 photovoltaic power stations have generated about 12,409,500 kilowatt-hours of electricity. Since the implementation of the targeted poverty alleviation work in Badong, the infrastructure construction has been continuously improved to solve the problem of drinking water for villagers, complete the construction of cement roads, gravel roads, drainage and irrigation channels, reservoirs and other projects, and complete the task of removing 23,638 people from the vulnerable areas of 7,244 households. We will vigorously develop the construction of tourism, education, medical treatment and production projects, develop star-level farmhouse, and continue to promote the establishment of "famous tourist towns in Hubei" and "famous tourist villages in Hubei".

\subsection{The poverty alleviation effect of the advantageous industry is remarkable.}

Badong county actively promotes the industrialization of poverty alleviation, development of characteristic industries to drive farmers' income, the county has completed the development of traditional Chinese medicinal materials $250,000 \mathrm{mu}$, tea $153,100 \mathrm{mu}$, citrus $115,000 \mathrm{mu}$, vigorously promote the development of "one township, one village, one product" characteristic industries, the leading industries of medicine, fruit, tea rapid development. Leading enterprises, professional cooperatives, family farms and e-commerce enterprises are fully connected with poor villages and poor households. Adhering to the development philosophy of "branding, standardization, specialization, scale and specialty", badong has developed a featured poverty alleviation road through online, offline, e-commerce, wechat business and other forms.

\subsection{Technology poverty alleviation-oriented, integrated poverty alleviation funds.}

To strengthen farmers' technology, organized by county audit bureau in our task force provide farmers with 15 days of skills training, training content mainly covers the papaya, oranges, chestnuts, planting technology and sow breeding technology, take the way of combining theoretical explanation and on-site guidance, the answer to the villagers. As a whole, the funds are mainly used for production development, education, ecological compensation, relocation of poor people from inhospitable areas, social security, health, culture, wisdom, rural infrastructure construction and skill training. 


\section{PROBLEMS IN THE PRACTICE OF PRECISE POVERTY ALLEVIATION IN BADONG COUNTRY}

\subsection{Accurate identification of poverty alleviation is difficult.}

In order to make people out of poverty, on the one hand, the concept of farmers still stays in the thought of "etc., on, to", "to" the thought is very outstanding, poor phenomenon is serious, unable to find out the truth of poor families, intentionally hide the income and ability to work in the home, let the superior cadre is difficult to make a judgment; On the other hand, in the targeted poverty alleviation work, due to the large number of poor people, the workload is large, the time is tight, and the lack of attention to poverty alleviation work causes the problem of accurate identification.

\subsection{The limitation of industrial development makes it more difficult to help the poor.}

Badong county different towns and villages such as climate, natural resources, terrain conditions, the village collective without consideration of local conditions, taking advantage of the regional resources, blindly follow suit, see other villages planting of agricultural and sideline products have obtained a better income, they will introduce this kind of product, cost a great deal of manpower and material resources and financial resources, waste of resources, caused the industrial structure is unreasonable, the farmers' income down, poverty has become more difficult.

\subsection{Neglect of education.}

In the organization of education and training work, due to the lack of attention to training work, hire unprofessional experts, training work is aimed at training, copy, ignore the content of the actual needs, lack of pertinence. As a result, most farmers do not want to participate, thinking that it is a waste of time and can not be fully used in practice. In addition, the cost of rural education and training is seriously insufficient, and only basic education is attached importance to while vocational education and training are neglected, thus reducing the progress of poverty alleviation of the poor population.

\subsection{It is difficult to play the advantage of helping in the village.}

Village support in the development of work to do the post in the village, eat and live in the village, work in the village, but the effect is not obvious. On the one hand, some cadres in villages lack experience in rural life, so it is difficult to introduce good projects to poor villages to bring benefits to farmers. On the other hand, although the cadres in the village have a wide range of knowledge, they are difficult to play a corresponding role in helping the village-level "two committees" to clarify their development ideas and formulate village-level poverty alleviation plans.

\section{COUNTERMEASURES AND SUGGESTIONS IN THE PRACTICE OF PRECISE POVERTY ALLEVIATION IN BADONG COUNTRY}

\subsection{Further improve the recognition mechanism and change the traditional concept of farmers.}

In accordance with the requirements of "households have CARDS, villages have books, towns have books, and counties have files", the villagers shall declare by themselves according to the procedures, and democratic selection shall be conducted in the village, town, and county level bulletin boards. Taking development as the fundamental way to solve poverty, the mode of education and wisdom support is to change the thinking and improve poverty alleviation skills. In this mode, children in poor areas can receive good education in order to prevent the inter-generational transmission of poverty ${ }^{[2]}$. Giving money and goods can only solve the temporary difficulties of poor households, but cannot restore the hematopoietic function of poor areas.

\subsection{Focus on sustainable development of poverty alleviation projects.}

We will vigorously develop leading industries such as tea, medicinal materials, penggan, and take suburban advantages, rural tourism and whole fishing tourism as the main line to promote the integration of rural tourism and cultural tourism, so as to achieve full coverage of industrial employment. Promote the company + base + professional cooperatives + farmers + scientific research institutes of industrial operation mode, vigorously develop professional cooperatives. We should pay attention to supporting poverty alleviation projects in terms of policies, funds and talents so as to ensure their sustainable development and ensure the stability of poverty alleviation work.

\subsection{Increase funding for education and training for farmers.}

The government should increase financial input in vocational training for farmers, increase publicity efforts, so that farmers realize the importance of training for rural development and income increase, hire agricultural experts 


\section{REFERENCES}

funds, so that the training can be carried out smoothly.

\subsection{Strengthen the training of village cadres and establish a long-term mechanism for village-based task forces.}

We should strengthen the training of cadres in villages, and train them in ideology, skills, communication and responsibility, so as to improve their ability to help the poor. At the same time, more than 80 percent of the cadres in townships and towns can work in villages, eat and live in villages, and work in villages, so that they are close to the poor population, so as to ensure that "the strength of cadres is sinking". We will improve the efficiency of supporting and tackling problems and achieve sustainable poverty alleviation.

\section{ACKNOWLEDGMENT}

In the process of poverty alleviation, the most important is "precision", farmers can get rid of poverty and become rich, so that they can live a happy life, We will not leave behind any village, one person or one household to achieve common prosperity and build a moderately prosperous society in all respects at an early date.
[1]Wang Meiwen, WeiWei. Empirical Analysis of the Difficulties of Precision Poverty Reduction in Rural China-Take the Case of Badong County, Enshi Autonomous Prefecture, for example, Journal of Kaifeng Institute of Education,2018,38(02):278-279.

[2]Wang Chao, Jiang Bin. Study on the innovative ecosystem of rural precision poverty alleviation under the background of rural revitalization strategy[J].Journal of Sichuan Normal University (Social Science Edition),2018,45(03):5-15.

[3]Xu Hanze, Li Xiaoyun. The practical dilemma of rural industry poverty alleviation under the background of precision poverty alleviation-A study of the industrial poverty alleviation project in Li village in North China. Journal of Northwestern University of Agriculture, Forestry and Technology (Social Science),2017,17(01):9-16.

[4] Yu jingyi. Research on targeted poverty alleviation in China -- a case study of changling county, jilin province [J]. World of labor security,2019(20):16-17 